\title{
Mean platelet volume in monitoring of brucellosis
}

\section{Bruselloz takibinde ortalama trombosit hacmi}

\author{
Çiğdem Kader*, Sadiye Yolcu, Ayşe Erbay
}

Department of Infectious Diseases and Clinical Microbiology (Assist. Prof. Ç. Kader, MD, Prof. A. Erbay, MD), Department of Emergency Medicine (Assist. Prof. S. Yolcu, MD), Bozok University School of Medicine, TR-66200 Yozgat

Geliş tarihi/Received: August 20, 2013; Kabul tarihi/Accepted: December 04, 2013

\section{*Corresponding author:}

Dr. Çiğdem Kader, Enfeksiyon Hastalıkları ve Klinik Mikrobiyoloji Anabilim Dalı, Bozok Üniversitesi Tıp Fakültesi, TR-66200 Yozgat. E-mail: dr_cigdemtr@yahoo.com

\section{To the editor}

We read the letter entitled "Mean platelet volume may not be a biomarker monitoring of brucellosis" and we wanted to answer the queries of the authors.

Brucellosis is a systemic zoonotic infection and still an important public health problem in many geographical parts of the world. Brucellosis infection spreads hematogenously to tissues and mainly affects organs rich in mononuclear phagocytes, such as the liver, the spleen, the lymph nodes and the bone marrow [1]. In humans, the disease may cause many symptoms varying from mild flu-like to severe complications on the part of the nervous system, musculoskeletal system and the heart [2].

Platelet count and white blood cell count are the markers that reflect the inflammatory response [3]. Mean platelet volume (MPV) is a parameter of complete blood count (CBC) analysis and is usually used by clinicians [4]. The authors suggested that the platelet indices including MPV are not used to assess for platelet function. But Gasparyan [4] showed that MPV correlates with the platelet function and activation. Previous studies have shown that MPV is a reflection of both proinflammatory and prothrombotic conditions, where thrombopoietin and numerous inflammatory cytokines (IL-1, IL-6 and $\mathrm{TNFa}$ ) regulate thrombopoiesis. The intensity of systemic inflammation can be viewed as a distinctive factor for classifying conditions associated with large and small-sized circulating platelets [4]. MPV is an indicator of the average size and activity of platelets.

Large platelets are younger, more reactive and aggregable. They contain denser granules, secrete more seretonin and b-thromboglobulin, and produce more thromboxane A2 than smaller platelets. Overproduction of proinflammatory cytokines and acute-phase reactants can suppresse the size of platelets by interfering with megakaryopoiesis with subsequent release of small size platelets from the bone marrow. It is known that large platelets are more active in releasing a variety of proinflammatory and thrombotic agents than smaller size platelets and their demand is increased during acute stage of inflammation [4-6].

Because of systemic involvement and inflammation of brucellosis it can not be said that this disease is not related with platelet activation and function. But of course further more comprehensive prospective studies are needed about MPV use in monitoring of Brucellosis. 


\section{References}

1. Ekici MA, Özbek Z, Kazancı B, Güçlü B. Collapsed L4 Vertebral Body Caused by Brucellosis. J Korean Neurosurg Soc 2014; 55: 48-50.

2. Galińska EM, Zagórski J. Brucellosis in humans--etiology, diagnostics, clinical forms. Ann Agric Environ Med 2013; 20: 233-8.

3. Sandhaus LM, Meyer P. How useful are CBC and reticulocyte reports to clinicians? Am J Clin Pathol 2002; 118: 787-93.

4. Gasparyan AY, Ayvazyan L, Mikhailidis DP, Kitas GD. Mean platelet volume: A link between thrombosis and inflammation? Curr Pharm Des 2011; 17: 47-58.

5. Champion HR, Sacco WJ, Copes WS, Gann DS, Gennarelli TA, Flanagan ME. A revision of the Trauma Score. J Trauma 1989; 29: 623-9.

6. Hekimsoy Z, Payzin B, Ornek T, Kandoğan G. Mean platelet volume in Type 2 diabetic patients. J Diabetes Complications 2004; 18: 173-6. 